folk/ed. Derg, 2022; 28(1)-109. sayı

DOI: $10.22559 /$ folklor.2072

\title{
Representation of Myth, Folklore and Oral Tradition in Gao Xingjian's Soul Mountain
}

\author{
Gao Xingjian'ın Ruh Dağında Mit, Folklor ve Sözlü \\ Geleneğin Temsili
}

\section{Anurag Bhattacharyya*}

\begin{abstract}
Gao Xingjian is a Chinese Nobel Laureate in Literature best known for his renowned novel Soul Mountain that traces the five month journey of the protagonist from the source of the Yangtze River till it meets the China Sea. The unnamed narrator makes a trip to the remote places of the eastern China bordering Tibet and highlights the ravages caused by Cultural Revolution under the leadership of Mao Zedong. In the name of development and in their bid to embrace modernity the Red Guards completely destroyed the people's sense of rootedness to their land and place and imposed a kind of forced amnesia that compelled them to adopt a life that is artificial and alien to these people. Gao Xingjian in his novel explores the dreams and oral folk narratives of the minority community and also explores
\end{abstract}

Geliş tarihi (Received): 10-07-2021 - Kabul tarihi (Accepted): 17-01-2022

* Assoc. Prof.Dr., Department of English, Dibrugarh University, India. (Dibrugarh Üniversitesi, İngilizce Bölümü) Hindistan. anuragdu2009@gmail.com. ORCID 0000-0001-8619-4624 
the various myths, beliefs, legends and rituals that is integral to their culture. The paper seeks to examine the role of myths, folklore and oral tradition in preserving the characteristic form of civilization and its customs, legends, traditional knowledge, beliefs, superstition and cultures in oral tradition which are transmitted from generation to generation. It further makes an attempt to represent the traces of the buried past under the critical political situation. Soul Mountain makes a journey into the past of the nation and then used it as a source of imparting and preserving the ecological heritage of these indigenous people. The methodological tools of ecocriticism like indigenous ecocriticism, place, landscape, deep ecology, biocenticism have been applied for the analysis of the text.

Keywords: Gao Xingjian, indigenous ecocriticism, cultural memory, myths, landscape

\section{Öz}

Gao Xingjian, kahramanın Yangtze Nehri'nin kaynağından Çin Denizi ile buluşana kadar beş aylık yolculuğunu izleyen ünlü romanı Ruh Dağı ile tanınan, Çinli bir Nobel Ödülü sahibidir. İsimsiz anlatıcı, Doğu Çin'in Tibet sınırındaki uzak yerlerine bir gezi yapar ve Mao Zedong liderliğindeki Kültür Devrimi’nin yol açtığı yıkımı üzerinde yoğunlaşır. Kızıl Muhafızlar, kalkınma adına ve moderniteyi kucaklama çabalarıyla, halkın topraklarına ve yerine kök salma duygusunu tamamen yok etmiş ve onları yapay; bu insanlara yabancı bir yaşamı benimsemeye zorlayan bir tür zorunlu hafıza kaybı dayatmıştır. Gao Xingjian, romanında azınlık topluluğunun rüyalarını ve sözlü halk anlatılarını araştırıyor ve ayrıca kültürlerinin ayrılmaz bir parçası olan çeşitli mitleri, inançları, efsaneleri ve ritüelleri irdeliyor. Makale, nesilden nesile aktarılan sözlü gelenekte uygarlığın karakteristik biçimini ve geleneklerini, efsanelerini, geleneksel bilgilerini, inançlarını, hurafelerini ve kültürlerini korumada mitlerin, folklorun ve sözlü geleneğin rolünü incelemeyi amaçlamaktadır. Ayrıca kritik siyasi durum altında gömülü geçmişin izlerini temsil etmeye çalışır. Soul Mountain, ulusun geçmişine bir yolculuk yapar ve daha sonra onu bu yerli halkın ekolojik mirasını vermek ve korumak için bir kaynak olarak kullanır. Buradaki amacım,bu romanı çevresel bir perspektiften ve insanların toprak ve kültürle olan bağlarının nasıl biyosferin ekolojisinden ayrılmaz olduğunu incelemektir. Metnin çözümlenmesinde yerel ekoeleştiri, yer, peyzaj, derin ekoloji, biyosentizm gibi ekoeleştiri metodolojik araçları kullanılmıştır.

Anahtar sözcükler: Gao Xingjian, yerli ekoeleştiri, kültürel bellek, mitler, manzara

\section{Introduction}

Soul Mountain is an autobiographical novel that presents a five month journey of the protagonist from Beijing to Sichuan province and from there followed the Yangtze River to the coast. The novel uses pronouns instead of characters, psychological perceptions instead of plot, and changing emotions to modulate the style. The novel is similar to a travel diary, 
and also resembles a soliloquy. The novel recounts two journeys that are woven together by alternating uses of "you" and "I". The splitting of the character makes it possible for him to differentiate his journey across the vast regions of China, from the Tibetan plateau to the east coast via the middle valley of the Yangtze River. The "you" is looking for the unlikely place named "Soul Mountain", which is always being pushed further away, towards the "other shore". This essentially internal journey parallels the geographical crossing carried out by the "I". The description of this trip is supposed to be based on Gao Xingjian's journey along the catchment areas of the Yangtze River in 1983. During this journey as a political refuse from Beijing the author narrates about the individual's experience, and in order to escape from his inner loneliness he uses the technique of storytelling and also recreates his past and the physical landscapes from his memory. Soul Mountain begins with the narrator's leaving the "contaminated surroundings" and searching for an authentic life in nature. The impersonal city life sets the narrator off on a journey to the forests and the mountains in rural areas where the primitive practices of living an authentic life is preserved and minimally contaminated by modern civilization. Gao Xingjian made three trips to the Yangtze Valley during 1983 and 1984 in order to write his novel and dispel his loneliness arising out of his sense of uncertainty about his future as he had to impose rigorous self-censorship during the tenure of Mao Zedong. He travelled along the giant panda reserve which is the home of the Qiang people and he witnessed the performance of folk songs and rituals and finally he returned to urban life. The novel traces the journey of the author to give a detailed description of the life and culture of the remote mountains and also delineates the close relationship they shared with nature.

\section{Methodology}

For the purpose of the study I have examined Gao Xingiian's Soul Mountain which is specifically considered as a highly philosophical novel that presents the existential issues faced by an individual especially a writer who has been targeted for his works only because it is not in conformity with the ideology propagated by the state. My attempt here is to study his novel from an environmental perspective and how people's connection with land and culture is inseparable from the ecology of the biosphere. The theory of ecocriticism can be traced back to the publication of Rachel Carson's Silent Spring (1962) which is widely credited with helping launch the environmental movement. The book documented detrimental effects of pesticides on the environment, particularly on birds. Another pioneering work is The Ecocriticism Reader: Landmarks in Literary Ecology (1996), edited by Cheryll Glotfelty and Harold Fromm (1996) which is the first general reader in ecocriticism. Cheryll Glotfelty's introduction is invaluable in providing a background to the emergence of ecocriticism and an outline of its concerns. Glotfelty defines the term ecocriticism as "the study of the relationship between literature and the physical environment" (Glotfelty xviii). Another notable work that helped me a lot in the formulation of my hypothesis is Edward Relph's Place and Placelessness that examines that the changing nature of places through time. It further states that place must be understood with its relationship to space; from the way people 
experience it. The understanding of space is closely connected to places we live and draws its meaning from its spatial environment like modifications of urban structures and landscapes and its impact in our attitudes, when we revisit that place. These ideas have been applied in the interpretation and discussion of the novel. In addition to this some of the seminal texts that have contributed significantly towards the study of Gao Xingjian studies include Soul of Chaos: Critical Perspectives on Gao Xingjian (2001) edited by Kwok-Kan Tam is a collection of critical studies on various aspects of Gao Xingjian's novels and plays. Another notable work is Jessica Yeung's Ink Dances in Limbo: Gao Xingjian's Writing as Cultural Translation (2008) is a pioneering work that provides a critical introduction to Gao as a novelist and as a playwright. In Soul Mountain Gao Xingjian keeps a record of the myths and legends, customs and practices, folk songs and music, the art of singing, storytelling, dance and performances that centred round the sacrifices associated with Chinese tradition. For the purpose of this paper I have also incorporated the ideas included in the volume Ecocriticism and Indigenous Studies (2017) edited by Salma Monani and Joni Adamson. This book addresses the interconnections between ecocriticism and indigenous studies. The purpose of the paper is to examine the role of myths, folklore and oral tradition as discussed in Gao Xingjian's Soul Mountain and its role in preserving the characteristic form of civilization and its customs, legends, traditional knowledge, beliefs, superstition and cultures in oral tradition which are transmitted from generation to generation. It further makes an attempt to represent the traces of the buried past under the critical political situation. For the purpose of the study the methodological tools of ecocriticism like indigenous ecocriticism, place, landscape, deep ecology, biocenticism have been applied for the analysis of the text.

\section{Discussion}

Root-seeking Literature is a literary movement that started in the early 1980s, and is widely regarded as the most influential literary trend in post-Mao Chinese literature. Gao Xingjian is considered as a proponent of this movement and his search for roots is a kind of spiritual journey brought about by their sense of alienation towards urban life. They believed that the soul of Chinese civilization lies in the countryside because material aspects of modern life had only limited access in these areas. The agrarian society is considered to be at the heart of Chinese culture, uncontaminated by Western influences and hence thought to be the preserver of the primordial energies of humanity. This movement has been influenced by the West and especially by Latin American magic realism that identified old Chinese traditions as a source of a new literature that addressed these issues. Although the ancient roots that inspired the root-seekers were most often located in remote rural China, they also existed in the urban places and thus plays a major part in the novel. In Soul Mountain Gao Xingjian unearths the nation's past buried deep inside ancient regions and seeks to examine its relevance for the literary imagination. Han Shaogong who has started this movement stated that there was a gap between the ancient past and the present, and in the twentieth century, China had experienced a period of amnesia, in which the nation's glorious past has been wiped out from the collective memory of the Chinese. He further states: 
"The responsibility of a writer was to help the nation reconnect to its past, to "sort out", the cultural roots. Only by doing so, they argued, would Chinese literature be able to "dialogue" with the rest of the world. The goal of the root-seekers, therefore, was to search for authentic Chinese" (Ying, 159).

According to Kam Louie both Gao Xingjian and the Root Seeking School are preoccupied with one's nostalgia for the past that has been destroyed by the official history that made them search for alternative roots and the centre has always been traced in the south western region of the Yangtze River. While discussing the relevance of this Movement in her book titled Ink Dances in Limbo: Gao Xingjian's Writing as Cultural Translation Jessica Yeung states:

"The spirit of the movement in search of cultural roots, however, is not merely to return to old traditions, but to promote an awareness of the relationship between modern life and old traditions, since advocators of the movement believe that a great deal of the values upheld in Chinese culture at present, and especially the obscure ones, are related to traditional Chinese lives and habits" (100).

The novel thus seeks to represent the historical and anthropological aspects of the ethnic Chinese minorities through the use of imagery, written in a unique style akin to traditional Chinese literary genres. Gao Xingjian firmly asserts that the writer plays the role of a witness and reaches deep into the inner workings of reality. Particularly in the context of an authoritarian regime when the freedom of a writer has been curtailed literature can play an important role in finding the truth and can fill up the gaps of history. In Soul Mountain Gao Xingjian stresses on the necessity of fleeing for 'self-preservation'. In 'Literature and Metaphysics" Gao states:

"I have studied inscriptions from the ancient states of Ba and Shu, the bird script on Yue swords and the silk paintings of Chu tombs. I have investigated the ancestral sacrifices carried out by Miao shamans and I have listened to the Yi classics sung by their bimo priests. I have wandered along the Yangtze, from the giant panda reserve that is the home of the Qiang people right down to where it meets the China Sea, and from folk customs and practices I have returned to urban life. I was searching for self-realization and a mode of living for myself (103)".

\subsection{Return to nature}

Ecocriticism represents place in a particular way not just by naming objects but by dramatizing in the process how they matter. Place attachment thus becomes a resource in the articulation of environmental unconscious (Buell 21). The novel depicts the schizophrenia perpetrated during the Cultural Revolution, that led Gao Xingjian to develop an intense personal philosophy which he had used to escape from the political turmoil that threatened to physically and mentally squash him. The origin of the novel Soul Mountain can be traced back to two traumatic experiences in Gao Xingjian's life-firstly he has been targeted for criticism during the Cultural Revolution and secondly 
he was wrongly diagnosed as having lung cancer. This close encounter with death and later his escape as a result of wrong diagnosis that was indicated in the last X-ray or supernatural intervention that has completely cured him taught him to accept life with a renewed vigour and freshness. This has brought about a transformation in his attitude towards life and he listened to his inner voice that he should return to nature to search for an authentic life. The narrator makes an attempt to return to the simple and authentic life, which the protagonists find in the folk narratives and oral tradition of the ethnic tribes. Such ethnographic constructions of self-identity through tales and narratives aims at creating a new world for themselves within which not only their beliefs would find a place but they would also constructed a place of wisdom that can transcend the borderlines of reason.

The journey of the narrator in Soul Mountain takes place at two levels-physical as well as spiritual which has been demonstrated by alternating imagination and reality, the narrator seeks a form of totality and authenticity in the origin of Chinese civilization, the true nature of his self, his search for truth and a return to pristine natural environment untouched by modern culture. Thus Soul Mountain is a fictionalized account of an ethnological research project that aims to unearth forgotten, threatened, and marginalized cultures, pointing to the hierarchies within the political frontiers, and dissenting from the official creed and common discourse on the subject. His return to the sources does not in any way serve to magnify national culture, but rather to condemn discrimination and overshadowing. It presents a series of field research enriched with philosophical, historical and literary meditations. There are numerous references that include visits to remote temples and villages, the collecting of local songs and customs, the adaptation of stories and legends, all confer a deliberately composite construction of this ethno text. Reading Soul Mountain enables a reader to get acquainted with the vast cultural landscape of China and his method of depiction of diverse communities, customs and practices is a reflection of his love for his country. As Gao Xingjian in his essay "The Voice of the Individual" states:

"I am a Chinese writer, only one person, and I cannot represent others. China for me is not that huge race or abstract nation; it is simply the cultural background that manifests itself in my writings, the culture's impact on me since my birth, and the modes of thought, nurtured by the Chinese language, that I use in my writings" (129).

\subsection{In search of cultural memories}

In Soul Mountain there is a detailed description of an old mask in Chapter 24. The protagonist saw it in a museum in the southern province of Guizhou, a region which is home to ethnic minorities. The mask has sharp realistic features, with a pair of horns on the top of its head, two sharp fangs rising up towards its nose, and two eyes with holes in them, giving it a threatening and anxious expression. This mask most likely "represents the god who opens the mountain 'Kaishan' or the god who opens the road at the beginning of the ritual" (Zhang 25). The novel examines the concept of "environmental landscape" which unites human and spirit dwelling places, including forests, mountains, and rivers. 
Oral histories, myths and folktales ballads, ritual incantations and ordinary stories of daily life all invoked in real or imagined detail the spatial positioning of a community. All these factors are responsible for giving an identity to a place. Any attempts to alter the features of a place in the name of development or progress led to the depletion of the cultural richness of that region. Soul Mountain contains many references to Daoist myths and symbols. The protagonist visited numerous remote villages inhabited by ethnic groups. He also explored nature reserves with ancient forests and the giant panda, isolated monasteries and temples that provide a witness to folk culture: myths and customs, folk songs and dance associated with shamanistic practices. He has witnessed the degraded natural environment in south west China and expressed his concern for the destruction of the environment for the survival of human species alone which is a matter of concern for the future of the ecosystem. The narrator clearly mentions clear cutting of forests, siltation of rivers, and the environmental threat posed by the Three Gorges Dam:

\begin{abstract}
"The Min River has turned into a black muddy river but the Yangtze is much worse yet they are going to block off the river and construct a dam in the Three Gorges... Needless to say, blocking off the river and putting up a dam will destroy the entire ecology of the Yangtze River basin but if it leads to earthquakes the population of hundreds of millions living in the middle and lower reaches of the Yangtze will become fish and turtles!" (Soul Mountain 48).
\end{abstract}

There are numerous chapters in the novel that are made up of folk legends and stories in which the styles and techniques of oral literature are adopted. During his visit to the remote places he gets rejuvenated by the sight, sound and scent of nature in which the poet forget his difficulties and troubles are attached with urban lifestyle and he found harmony with nature. His search for true life in Soul Mountain becomes an attempt to return to the authentic life, which the protagonist finds in the folk songs of the ethnic tribes such as the Qiang and the Miao. He collects these songs as he finds a close relationship between the human- nonhuman and his search for an authentic life is clearly depicted in these old songs. In Chapter 41 the narrator describes the ox sacrificial ceremony of the Miao community. This ritual is associated with some songs. Before the sacrifice a decorated pillar had to be erected on the ground. The members of the family put on new dress and there is a fanfare of pipes and the beating of gongs and drums. A rope is tied to the ox's nose, wrapped its horn in bamboo wreaths and brought it out. The male head of the family sang loudly a eulogy took up a spear and stabbed the ox:

\footnotetext{
"Ox oh ox, Born in still waters, Growing up on sandy banks, You cross rivers with your mother, You climb mountains with your father, Fight the locusts for the sacrificial drum, Fight the praying mantis for the sacrificial pipes" (Soul Mountain 239).
}

The novel makes a strong connection between the places visited on the journey and the practices of the age old Chinese cultural traditions behind the landscape. Land is always treated like a text with cultural and literary meaning embedded in it and the narrator visited these places in his search for cultural memories. The protagonist visits 
various remote villages, ethnic groups, nature reserves with ancient forests which is the habitat of the giant panda, isolated monasteries and temples, and has witnessed ancient folk and shamanistic practices. The chapters also contain large segments of conversations, folk songs and chants that examine how primeval instincts are repressed by the modern civilization and it also demonstrates the futile efforts during the Cultural Revolution to eradicate these superstitious practices. Gao Xingjian superimposes fiction on personal accounts, and expresses his viewpoint that is both critical and self-reflective, pondering upon the orchestrated amnesia and personal forgetfulness. The author tried to preserve buried minority cultures, which are the casualties of the ravages of dominant culture, protecting his dislodged fragments of memories are woven into his personal history, questioning established historiography, and finally, continued his journey in search of truth and self. There is also reference to a biji tale of Jin Dynasty that comprises of anecdotes, quotations, random musings, philosophical speculation which is on the verge of extinction. There is no explanation given at the end of the story but just provides a hint that it a political one or could be turned into a religious tale. The novel is a by-product of the root-seeking school that is concerned with individual explorations of and nostalgia for imagined pasts. These official histories, be it Confucian or Communist, portrays China as if it is centred in the north, with Confucius, Beijing and the Yellow River as prominent cultural symbols. The search for alternative roots, however, took the 1980s writers south, with the poet $\mathrm{Qu}$ Yuan, the wilderness of the southwest and the Yangtze River as cultural icons. He records the incantations and magical procedures, the ritual dances, the ballads and funeral chants, which he sees as incarnations of a primeval vitality that will not tolerate any policy of homogenization. Love songs echo in the depths of the valleys, expressing a spontaneity that becomes scarce in classical poems, imprisoned in the rules of prosody. The narrator during his visit to the Guizhou Province witnesses the folk tradition of Yi community. Yi people are mostly located in the delta regions of the Jinsha River and its tributary the Yagong River. Their earliest ancestors are the Qiang people. "The Yi women have dark skin; a high nose bridge and long eyes and they are very beautiful" (117). Young people who fall in love can only meet secretly in the mountain. Yi love songs all seem to be "sad and tearful outpourings". The narrator's guide told him that marriages are still arranged by their parents among the Yi people. He further expresses the lamentation of the young people who fell in love could only meet secretly in the mountains:

"A pigeon and a chicken search for food together, the chicken has an owner but the pigeon does not. If the owner of the chicken takes the chicken home, the pigeon is left all alone a girl and a boy play together the girl has an owner but the boy does not, if the owner of the girl takes her home, the boy is left all alone (Soul Mountain 118).

The narrator also meets a bimo, the Yi priest who is singing a funeral dirge written in the ancient Yi language. The sustained rising and falling crescendo of the high pitched singing of the bimo rises from the throat, hits the back palate, passes through the nasal cavity causing it to resonate, then charges out through his forehead. During the funeral procession that he witnesses: "people beating gongs and drums, blowing the suona, carrying flags on 
poles, paper people, and paper horses. The women are riding on horses and the men have rifles which they fire along the way" (120). The narrator also visits the house of the Daoist singer to watch the performance of Daoist rituals. After travelling twenty kilometres in a bus he arrived at a small town. Finally he arrived at a little mountain village where incense was burning as an offering to the large number of wooden and stone carvings. He believed that these were rescued from the Daoist temple some years ago when the 'four olds' (292) were destroyed and temples and monasteries were smashed. During the actual performance of the rituals the old man was wearing a tattered old purple Daoist robe adorned with the insignia of the Yin-Yang fish and the eight Trigrams, and was carrying the command tablet, the sword of office and an ox horn. As a part of the ritual the Daoist singer took a bowl of clear liquid and, chanting, flicks the watery liquor into the four corners of the house. His eyes partly close, his mouth slackens and his face takes on a serious look, as if he is communicating with the spirits. Next he made a string of incantations to invoke the spirits of Heaven and Earth.

\subsection{Landscape and myths}

Landscape refers to the perceived settings that frame people's senses of place and community. A place is a socially meaningful and identifiable space to which a historical dimension is attributed. Everything that originated in that part of land including the customs and traditions and also the myths are inextricably connected to the place. This concept has been clearly discussed in Soul Mountain by referring to an episode of a girl who committed suicide by drowning in the river. Her body was found thirty $l i$ downstream at Xiashapu and the upper part of her body was bare, and her shirt got caught on a branch in a bend of the river. She had left her sports shoes on a rock and later on 'Yu Crossing' (Soul Mountain 42) was curved into the rock and painted in red and it has turned into a favourite spot for tourists who climbed to the top for taking photographs. This explains how a physical space endowed with meaning turns into a landscape-a contextual horizon of perceptions, providing both a foreground and a background in which people feel themselves to be living in their world:

\footnotetext{
"People used to die at this spot all the time, you say, and they were very often children and women. Children would dive off the rock in summer, the ones who didn't re-surface were said to have been trying to die and had been reclaimed by parents of another life. Those forced into taking their own lives are always women - defenceless young students sent here from the city, young women who had been maltreated by mothers-inlaw and husbands (Soul Mountain 54).
}

Places depicted in Soul Mountain have its own unique pattern and meaning has been etched into it. According to Tuan every place is constructed by experience whether it is home, country side, urban spaces, wilderness, or it may be any form of space. Gao's idea of physical environment exhibits various spatial patterns on different scales- biological organisms organized into populations and spread across landscapes. Gao Xingjian's Soul 
Mountain presents a landscape which is as diverse and complex, as it is sublime and abounds with beauties of nature. The most salient feature that characterizes his idea of landscaping is the sense of place associated with it and an awareness of nature-human relationships including one's connection with the mythical environment. Human beings attribute special and often personal meanings to places, such as places where they spent their childhood or where they relate to special events. People from different cultures can recognize and interpret the same place in different ways. Thus landscape is constructed as a result of a shared system of beliefs and ideologies. The use of landscape in Soul Mountain can be seen as a cultural construct that includes a sense of place and memories. In this way, landscapes are cultural objects, that reservoir of our memories and myths, encoded in a sense that can be read and interpreted. Simon Schama argues in Landscape and Memory that "landscapes are culture before they are nature; constructs of the imagination projected on to the wood and water and rock" (61). He further lays emphasis on the fact that once a certain idea of landscape, a myth or a vision establishes itself in an actual place, that that space becomes a part of the cultural scene. Therefore humans lives have influenced, and been influenced by landscapes. In this way landscape is a cultural construct, a mirror of our memories and myths encoded with meanings which can be read and interpreted. Soul Mountain presents in detail the folktales, oral histories, ethnography, ballads and ordinary events of daily life all invoked in the spatial positioning of a place. The novel presents a lively vision of the customs, folk songs and traditions preserved by national minorities, most of which have been lost among the Han people. These songs provide valuable insights into understanding the 'ethnoecology' (McLaren 4) of the region. Ethnoecology has been defined as a "traditional set of environmental perceptions-cultural model of the environment and its relation to people and society" (Kottak 26). The author in his search for roots come across Shamans, Buddhist and Daoist monks, singers, and records those experiences and recreates history and mythology of the people around him. He attempts to amalgamate history and reality blend with mythology and oral tradition that unifies the past and present; blending with history and folklore. In his search for cultural roots the protagonist expresses his desire for reconciliation of the individual with the history, culture and ecology of China.

\section{Conclusion}

The theory of ecocriticism and indigenous studies emerged out of the same long, entangled, historical roots. The paper articulates the importance of oral traditions and indigenous literature and its relevance with regard to nature and its attachment to place. The narrator achieved the state of highest wisdom in his intimate moments that he shares amidst nature. He recognizes the transience of all things that is beautiful, a sense of freedom and the ideal of tranquillity amidst nature. Towards the end of the novel he realizes that the "universe as a vast integrated unit, not as discrete mechanistic parts. Nature is seen as unified, interconnected and interpenetrating, constantly relating microcosm and macrocosm" (Swearer 52). This implies a kind of great chain of being, linking inorganic 
and human life forms. This is seen as the unifying element of the cosmos and creates the basis for a profound reciprocity between humans and the natural world. The novel fully acknowledges the biocentric principle embedded in Daoism that stresses the fact that man is only one part in a huge and complex life net in nature in which everything has a certain value. The novel sees the world as a vast interrelated network in which the universe and all creatures in it are acting in natural response and mutual interdependence. Ecocriticism thus seeks to understand cultural artefacts from an ecological perspective. Its main purpose is to initiate a dialogue between literature and the issue of environmental crisis like the climate change and global warming and examines the fact that these are not just issues arising out of simply technological and political implications but it also affects the culture and tradition of a civilization. Ecocritics have contributed a lot towards conservation of the ecosystem by creating awareness in the younger generation the need for restoration of their folklore, myths and oral tradition and its relationship with the land. Thus the understanding of the local customs and traditions of the indigenous people are intricately connected with the living and the non-living entity of the ecosystem and it is integral to the sustenance of the physical environment and the biosphere. For the purpose of future research it would be quite interesting to study Gao Xingjian's works from the perspective of Daoism and other non-western approaches to Environmental Humanities.

\section{References}

Barua, K. and A. Bhattacharyya. (2016). Place, landscape and self in Gao

Xingjian's Soul Mountain. in (S. C. Estok, I-Chun Wang and J. White. Eds)

Landscape, Seascape and the Ecospatial Imagination. Routledge. 197-208.

Buell, L. (1995). The future of environmental criticism: Environmental crisis and literary imagination. Blackwell.

Carson, R. (1999) Silent spring. Penguin.

Glotfelty, C. and H. Fromm. (1996). The ecocriticism reader: Landmarks in literary ecology. University of Georgia, 1996.

Kottak, C. P. (1999). The new ecological anthropology. American Anthropologist New

Series, 10:1, 23-35.

McLaren, A. E.(1994). Folk ecology and epics in rural China. Asian Studies Review

$18.1,77-88$.

Moran, T. (2002). Lost in the woods: Nature in Soul mountain. Modern Chinese

Literature and Culture, 14.2, 207-36.

Lee, M., (2007). Literature and metaphysics: About Soul Mountain. The Case for

Literature. Yale University Press, 82-103.

Lee, M., (2007). The voice of the individual. The Case for Literature. Yale University Press, 126- 139. 
Louie, K. (2001) In search of the Chinese Soul in the Mountains of the South. The China Journal, No. 45, 145-49.

Miller, J.( 2003). Daoism: A short introduction. Oneworld.

Monani, S. and J. Adamson. (2017). Ecocriticism and indigenous studies: Conversations from earth to cosmos. Routledge.

Xingjian, G. (2001). Soul mountain. Trans. M. Lee. Harper Perennial.

Yeung, J. (2008) Ink dances in Limbo: Gao Xingjian's Writing as Cultural Translation.

Hong Kong University.

Relph, E.(1976). Place and placelessness. Pion Limited.

Schama, S. (1995). Landacape and memory. Alfred A. Knopf.

Swearer, D. K. (2009). Ecology and the environment: Perspectives from the humanities.

Harvard University.

Tam, K. (2001). Soul of chaos: Critical perspectives on Gao Xingjian. The Chinese University.

Tuan, Y. (2001). Space and place: The perspective of experience. University of Minnesota Press.

Ying, L. (2010) Historical dictionary of modern Chinese literature, The Scarecrow. Zhang, Y. (2010) Gao Xingjian and Forbidden Memory. China Perspectives, 25-33. 